\title{
Индоевропейское происхождение поэтического языка «Слова о полку Игореве»: грамматические свидетельства*
}

\author{
НАЗАРИЙ НАЗАРОВ \\ Институт филологии Киевского национального университета имени Тараса Шевченко, \\ бульв. Тараса Шевченко, 14, UA-01601 Киев \\ E-mail: nazarmia@gmail.com
}

(Received: 9 December 2014; accepted: 24 March 2015)

\begin{abstract}
The aim of the present study is to show that the poetic language of Slovo o polku Igorever can be traced back to the common Indo-European poetic thesaurus. The study focuses on the hymn-like fragments of the Slovo: Yaroslavna's lament and Sviatoslav's golden word. The novelty of the approach is the special attention to the sequences of morphemes in the texts that can be distinguished as reflections of the Indo-European hymn (besides Slovo's fragments, also Ukrainian folklore texts, Homeric prayers, Homeric hymns, Orphic hymns, and Old Latin charms were analyzed). The grammatical comparison showed that each compositional part of the hymns has its own characteristic morphological features of common Indo-European origin. Furthermore, morphological devices are chained in series that are stable and function as base for the composition of the hymn. The use of morphological formants should have been determined by oral tradition because from the range of semantically close formants of a distinctive language only one is chosen, cognates of which are used in other analyzed traditions. It leads to the conclusion that orality and authenticity of the Slovo's hymn-like fragments are supported by the common Indo-European morphological chains.
\end{abstract}

Keywords: Slovo o polku Igorevě, Indo-European poetics, formula, orality

...славянская традиция составления архаических мифопоэтических и обрядовых текстов прямо продолжала индоевропейскую. Истоки древнего литературного языка славян восходят к общеиндоевропейской поэтической речи...

(ИвАНОВ 1979: 25)

Задача настоящей статьи состоит в том, чтобы апробировать еще один возможный метод реконструкции индоевропейского поэтического языка. В индоевропейской сравнительной поэтике исследовались более конкретные следы общего состояния, воплощенные в лексике, фразеологии, метрике. Предлагаемый нами метод объединяет фольклористический и лингвистический (структуральный) инструментарий и оперирует более абстрактными, но от того не менее материальными единицами, которые мы назвали последовательностями морфем и грамем. Он же может быть еще одним методом проверки аутентичности фольклорного текста.

* Автор хотел бы выразить благодарность за плодотворные обсуждения статьи д. филол. наук Ю. Л. Мосенкису и канд. филол. наук Д. И. Переверзеву. 
В исследовании текстов мы исходим из того, что если языковые особенности «Слова» происходят от общеиндоевропейского прототипа, то он будет отображен на всех уровнях текста: как на композиционном, так и на морфологическом. Из «Слова» мы избрали два фрагмента, которые на композиционном уровне могут быть рассмотрены как довольно самостоятельные по смыслу - это «Плач Ярославны» и «Золотое слово Святослава». Именно эти части «Слова о полку Игореве» на смысловом и композиционном уровнях полностью сохраняют жанровые признаки общеиндоевропейского религиозного гимна.

Однако если принимать во внимание только смысловой компонент, то могут возникнуть проблемы с разграничением аутентичного для данной традиции и заимствованного в более позднее время после распада языкового единства. Поэтому мы решили сравнивать тексты на том уровне, на котором заимствования почти или даже вовсе исключены - на уровне морфем, а точнее - их последовательностей. Мы предлагаем рассмотреть текст «Плача Ярославны» и «Золотого слова Святослава» с точки зрения теории устного сказительства Б. Лорда (см. LORD 1971), но с особенным вниманием к последовательностям морфем, предложенным нами. Б. Лорд оставил много идей для понимания формулы именно как грамматического ядра, по отношению к которому разные лексические реализации клише выглядят как инварианты. В таком случае каждая композиционная часть обоих анализированных фрагментов «Слова» представляется как разворачивание формулы, сводимой к условному исходному сочетанию грамем и соответствующих им морфологических средств.

Если морфологические последовательности «Слова» в самом деле происходят от индоевропейских, то в соответствующих композиционных частях греческих и латинских гимнов или заклинаний должны быть использованы морфемы, этимологически родственные славянским.

На самом ли деле это так?

Ответить на этот вопрос можно сравнивая тексты на тех языках, которые сохранили все индоевропейские грамматические форманты, ключевые для «Плача Ярославны» и «Золотого слова Святослава». Именно сохранность морфологического каркаса индоевропейского языка в разных дочерних языках и ограничивает круг текстов, которые могут быть привлечены к анализу. Если, например, вокатив есть почти во всех древних индоевропейских языках, то оптатив сохранился только в славянских (его форма переосмыслена как императив), греческом, санскрите, готском и латинском (только в парадигме глагола быть). На готском не сохранилось аутентичных, не переводных памятников, а древнеиндийские источники еще предстоит проанализировать в дальнейших исследованиях. Поэтому в этом исследовании мы сосредоточимся на греческих и латинских параллелях к «Слову», учитывая и сведения украинской фольклорной традиции. Последняя нужна для того, чтобы проверить, бытовали ли структуры, обнаруженные в «Слове», в устном творчестве или же они были характерны только для книжной эпики. 
Обычно балто-славянскому материалу не уделяли должного внимания в исследованиях индоевропейского поэтического языка (cp. Indogermanische Dichtersprache), за редкими (но основательными) исключениями - трудами В. В. Иванова и В. Н. Топорова (см. ИвАнов-Топоров 1963, ИвАнов-ТоПоров 1965: 218-239, Топоров 1969). В этот вопрос не достаточно углубился даже Р. Шмитт, автор такого фундаментального труда как «Dichtung und Dichtersprache in indogermanischer Zeit» (Sснмітт 1967; cp. также рецензии на него: RISCH 1969, LEONI 1968). Балто-славянскому материалу могло бы быть уделено больше внимания и во впечатляющей по своей полноте и охвату книге К. Уоткинса (см. WATKINS 1995). Однако М. Уэст считает, что в устной фольклорной традиции славянских и балтийских народов сохранились особенности поэтики, идущие напрямую от индоевропейского поэтического языка (WEST 2007). Среди письменных памятников славянских языков особенно благодатным материалом для таких исследований и вписания в широкий контекст индоевропейских поэтических традиций может быть назван язык «Слова о полку Игореве», объединенного сетью мотивных, сюжетных и мифологических связей со многими индоевропейскими традициями (МосЕНКИС 2006).

\section{Композиция общеиндоевропейского гимна...}

Самыми стойкими к временным изменениям оказываются структуры фольклорного текста, которые сопряжены с ритуальными и другими внеязыковыми измерениями. Поэтому ритуальные тексты (заклинания, гимны к богам) отличаются значительной однотипностью во многих родственных традициях, хотя время их расхождения иногда насчитывает многие столетия, а иногда и тысячелетия. Особенно хорошо эта проблема изучена на материале индоевропейской гимнографии, которая и будет значительным подспорьем в исследовании грамматических особенностей языка «Слова».

Независимо друг от друга несколько знаменитых индоевропеистов выяснили (что важно) на материале различных текстов древних индоевропейских традиций, что многие гимны индоевропейских народов восходят к единому композиционному прототипу. В. Н. Топоров, исходя из разительных параллелей в структуре од Пиндара и гимнов Ригведы, описал ее как трехчленную:

1) инвокация, номинация божества;

2) эпическая часть, описывающая мифологический прецедент, историю божества или предыдущее обращение к нему;

3) собственно молитвенное обращение к божеству с конкретными просьбами (ТопоРов 2012: 60-61).

Г. Надь, исследуя гомеровские гимны, обнаружил повторяющуюся последовательно во многих гимнах вступительную часть, которую нетрудно возвести к тому же прототипу гимна, который обнаружил В. Н. Топоров. Г. Надь описал эту последовательность так: 
1) призыв к божеству; именование бога;

2) перечисление эпитетов, указывающих на могущественность божества в рамках локального культа;

3) описание восхождения бога на Олимп и завоевание общегреческого признания;

4) молитва к божеству;

5) переход к остальной части гимна (НАдь 2002: 82).

Пункты 2 и 3 Г. Надя идентичны пункту 2 В. Н. Топорова, только описывают его более подробно. А что же касается (заключительного) пункта 5 Г. Надя, то он уже не касается структуры гимна как таковой. То есть в нашем исследовании будет целесообразно использовать трехчленную модель В. Н. Топорова, пункт 2 которой дополняют пункты 2 и 3 схемы Г. Надя. Более того, очень примечательно, что описанная выше трехчленная структура представляет собой часть выведенной Е. Г. Кагаровым «формулы» фольклорного заговора: $I$ - обращение, $E$ - эпическая часть (которая может иметь множество модификаций: указание к выполнению действий, мотив угрозы или награды, рассказ о мифологическом прецеденте в полной или в сокращенной до эпитета или имени форме), $L$ - лирическая (мольба, прошение), а также $B$ - мистические имена и $Z$ - заключительные слова (КАГАРОВ 1981: 73-74). В исследованных нами текстах последние два компонента не встречались.

Примечательно, что украинский фольклорист С. Я. Гординский, сравнивая обращение к Ярославу Осмомыслу в «Слове» с украинскими народными заклинаниями, приводит двухчастную схему (объединив инвокационную и эпическую части): после того как выяснено, какие именно действия сверхъестественного характера может исполнить стихия, к ней обращаются с просьбой (Гординський 1963: 27).

И, конечно, все композиционные части не обязательно встречаются во всех текстах, хотя бы отдаленно напоминающих гимн, однако представляют наиболее общую схему, как последовательность мотивов волшебной сказки В. Проппа, описывающей идеальную структуру, которая с разной полнотой реализовывается в текстах. Но в отличие от последней, трехчленная схема индоевропейского гимна характерна для очень многих текстов как в греческой, так и в древнеиндийской гимнографических традициях. А к анализу славянских реликтов этой схемы мы перейдем в следующем разделе.

\section{...и ее структуры, сохранившиеся в «Слове»}

Полностью соответствуют жанровому определению гимна обращения Ярославны к стихиям в ее плаче (от слов о вътръ! вътрило!). Каждое из таких обращений-микрогимнов в свою очередь можно разделить на части, соответствующие частям индоевропейского гимна, которые мы далее в статье будем именовать инвокационной (I), эпической $(\mathrm{E})$, лирической $(\mathrm{L})$. Ради удобства мы опустим комментарии «от автора», оставив только слова, которые он вкладывает в уста Ярославны (Таблица 1). 
Таблица 1.

\begin{tabular}{|c|c|c|c|}
\hline $\begin{array}{c}\text { Композиционные } \\
\text { части }\end{array}$ & Гимн №1 & Гимн №2 & Гимн №3 \\
\hline Инвокационная & о вЂтрђ! вБтрило! & $\begin{array}{l}\text { о Днепре слову- } \\
\text { тицю! }\end{array}$ & $\begin{array}{l}\text { свђтлое и тре- } \\
\text { свђтлое слънце! } \\
\text { чему господине }\end{array}$ \\
\hline Эпическая & $\begin{array}{l}\text { чему Господине на- } \\
\text { сильно въеши? Чему } \\
\text { мычеши Хиновьскыя } \\
\text { стрђлкы на своею не } \\
\text { трудною крилцю на } \\
\text { моея лады вои? Ма- } \\
\text { ло ли ти бяшеть горъ } \\
\text { подъ облакы въяти, } \\
\text { лельючи корабли на } \\
\text { синъ морь? Чему Гос- } \\
\text { подине мое веселіе } \\
\text { по ковылію развья? }\end{array}$ & $\begin{array}{l}\text { ты пробиль еси } \\
\text { каменныя горы } \\
\text { сквозъ землю } \\
\text { Половецкую. Ты } \\
\text { лельялъ еси на } \\
\text { себъ Святославли } \\
\text { носады до пльку } \\
\text { Кобякова: }\end{array}$ & $\begin{array}{l}\text { простре горя- } \\
\text { чюю свою лучю } \\
\text { на ладъ вои? въ } \\
\text { поль безводнъ } \\
\text { жаждею имь } \\
\text { лучи съпряже, } \\
\text { тугою имъ тули } \\
\text { затче. }\end{array}$ \\
\hline Лирическая & & $\begin{array}{l}\text { възлельй госпо- } \\
\text { дине мою ладу } \\
\text { къ мнъ, а быхъ } \\
\text { неслала къ нему } \\
\text { слезъ на море } \\
\text { рано. }\end{array}$ & \\
\hline
\end{tabular}

Однако такая четкая композиционная структура преобладает не только во фрагменте, известном как «Плач Ярославны». Эту же схему точно воспроизводит «Золотое слово Святослава», обращенное к князьям. ${ }^{1}$ Весьма примечательно, что раньше обращение к Галицкому Осмомыслу уже сравнивалось с народными украинскими заговорами на уровне лексики и стилистических формул (Гординський 1963: 25), и С. Я. Гординский пришел к выводу, что автор «Слова» воспользовался уже известной ему по фольклорным образцам формой заклинания (Гординський 1963: 26).

Прагматическая (в лингвистическом значении этого понятия) и ритуальная подоплека применения формы гимна в обращении к князьям полностью понятна из самого текста «Слова»: Святослав взывает к князьям с целью призвать их к единству, вселить в них боевой дух (что явно понималось весьма анимистически-конкретно самим автором, а тем более тем Святославом, которого автор «Слова» мог себе представить). Иными словами, Ярославна выражает свое беспокойство в магическом взаимодействии со стихиями (что полностью соответствует представлениям о женщине как близкой к сфере

${ }^{1}$ Даже название этого фрагмента, данное самим автором «Слова», имеет четкую индоевропейскую параллель: $\chi \rho \dot{\sigma \varepsilon} \alpha \alpha \dot{\varepsilon} \pi \eta$ Пифагора (нам неизвестно, чтобы названия этих двух текстов сравнивали раньше). 
природы), а Святослав - во влиянии на соратников, также соответствуя представлениям о мужчине как носителе цивилизационного начала человеческой природы. Но от этого его обращение не менее магично по своей природе, ведь композиционно, более того - грамматически, что будет дальше показано, оно целиком изоморфно и изофункционально «Плачу» Ярославны. Но (главное!) эти два фрагмента идут в тексте «Слова» почти один за другим: «Золотое слово» предваряет плач Ярославны, чем еще более подтверждается их жанровое и прагматическое единство.

Обращения к князьям отходят от формульной сжатости микрогимнов к стихиям, ведь это не целиком фольклорный по сути текст, а более поздний продукт культурной рефлексии, не утративший общих черт со своим прототипом. Поэтому приводим тут полностью только обращения к двум князьям (от слов Великый Княже Всеволод... и Галичкы Осмомысль Ярославе...), см. Таблица 2.

Таблииа 2.

\begin{tabular}{|c|c|c|}
\hline $\begin{array}{c}\text { Композиционные } \\
\text { части }\end{array}$ & & \\
\hline Инвокационная & Великый Княже Всеволод! & $\begin{array}{l}\text { Галичкы Осмомысль } \\
\text { Ярославе }\end{array}$ \\
\hline Эпическая & $\begin{array}{l}\text { не мыслію ти прелетьти } \\
\text { издалеча, отня злата стола } \\
\text { поблюсти? Ты бо можеши } \\
\text { Волгу веслы раскропити, а } \\
\text { Донъ шеломы выльяти. Аже } \\
\text { бы ты быль, то была бы Чага } \\
\text { по ногать, а Кощей по реза- } \\
\text { нъ. Ты бо можеши посуху } \\
\text { живыми шереширы стръля- } \\
\text { ти удалыми сыны Гльбовы. } \\
\text { Ты буй Рюриче и Давыде, не } \\
\text { ваю ли злачеными шеломы } \\
\text { по крови плаваша? Не ваю ли } \\
\text { храбрая дружина рыкають } \\
\text { акы тури, ранены саблями ка- } \\
\text { леными, на поль незнаемъ? }\end{array}$ & $\begin{array}{l}\text { высоко сьдиши на своемъ } \\
\text { златокованнъмъ столъ. } \\
\text { Подперъ горы Угорскыи } \\
\text { своими жельзными пль- } \\
\text { ки, заступивъ Королеви } \\
\text { путь, затвори въ Дунаю } \\
\text { ворота, меча времены } \\
\text { чрезъ облаки, суды рядя } \\
\text { до Дуная. Грозы твоя по } \\
\text { землямъ текутъ; оттворя- } \\
\text { еши Кіеву врата; стръля- } \\
\text { еши съ отня злата стола } \\
\text { Салтани за землями. }\end{array}$ \\
\hline Лирическая & $\begin{array}{l}\text { Вступита Господина въ злата } \\
\text { стремень за обиду сего вре- } \\
\text { мени, за землю Русскую, за } \\
\text { раны Игоревы, буего Свят- } \\
\text { славлича! }\end{array}$ & $\begin{array}{l}\text { Стрђляй Господине Кон- } \\
\text { чака, поганого Кощея за } \\
\text { землю Рускую, за раны } \\
\text { Игоревы буего Святслав- } \\
\text { лича. }\end{array}$ \\
\hline
\end{tabular}

Грамматический анализ обращений к стихиям и магических пробуждений силы в князьях позволяет найти общие морфологические черты, которые характерны для каждой композиционной части. При этом преимущественно 
обращают на себя внимание словоформы и морфемы, которые могут быть возведены к праславянским и индоевропейским прототипам.

Инвокационная часть состоит только из наименования стихии или князя в звательном падеже (вътрь, Днепре, господине, Великый Княже Всеволоде, Галичкы Осмомысль Ярославе, А ты буй Романе и Мстиславе!) который возводится к прасл. *-e и индоевропейскому конечному суффиксу основы *-e (BEEKES 1995: 186).

Эпическая часть более разнообразна в своем грамматическом и морфологическом оформлении (как и разнообразны по своему составу эпические части у Пиндара, в гомеровских гимнах и в Ригведе). Однако общего в анализированных местах из «Слова» тоже очень много: это употребление глагола 2-го лица единственного числа в настоящем и прошедшем времени. Старославянский и язык «Слова» не сохранили древнего претерита, заменив его формой причастия прошедшего времени $(-л,-8)$, что хотя не сохраняет индоевропейской морфологии, однако позволяет восстановить древнюю грамему.

Лирическая часть, как и инвокационная, отличается от срединной части однообразностью морфологических средств (об этой стабильности крайних частей, во всяком случае на мотивном и лексическом уровне, писал В. Н. Топоров). Характерной чертой этой части является императив глагола, который оформляется окончанием - $\breve{u}$, возводимым к прасл. *-jb, и к праиндоевропейскому оптативу *-ieh $h_{1}$ с возможным прибавлением окончания множественности *-te и двойственности *-ta (Мельничук 1966: 322). Даже в тех обращениях к князьям, где морфологическое оформление этой части редуцировано, императивность ясно узнается из эллиптического неполного предложения, как в обращении к Игорю и Всеволоду: Туга и тоска сыну Глъбову.

\section{Параллели в древнейших памятниках славянской словесности}

В одном из древнейших памятников славянской письменности, «Похвале Григория», первые слова каждой строчки прочитываются как акростих (ТопоРов 1979: 37). Эта краткая молитвенная формула сохранила лапидарно и четко отображение того же грамматического прототипа, к которому восходят заклинания «Слова»:

I. $\omega$ Григоре

E. ты бо оуста Бога правыл въры припадаькщь

L. приими и бжди ми просвьтитель и оучитель.

Фрагмент «Азбучной молитвы» Константина Философа от строчки, начинающейся на $\sigma$, до строчки на ж можно рассматривать как отображение той же схемы:

I. Боже, Е. всъи твари зижителю,

Видимыл и невидимыл,

L. Господа духа посли живоущаго, 
Да вдохнеть вь сердии мое слове,

Еже боудет на оуспьхъ всъм,

Живущиим в заповедех твоих (Куев 1974: 298).

\section{Параллели к индоевропейским компонентам «Плача Ярославны» и «Золотого слова Святослава» в языке украинских заговоров}

Как уже говорилось раньше, С. Я. Гординский обнаружил параллели к обращению ко князю Ярославу Осмомыслу среди украинских заклинаний. Однако провести параллели с «Плачем Ярославны» ему мешало отсутствие лексических совпадений. Мы же, используя сравнение более абстрактных структур текста, какими являются последовательности морфем, можем установить явные параллели между украинскими заклинаниями, которые С. Я. Гординский раньше сравнивал на лексическом и стилистическом уровнях, с «Плачем Ярославны» и «Золотым словом Святослава». Приводим оба текста так, как их цитирует сам С. Я. Гординский, с сохранением аутентичного написания (Таблица 3).

Таблица 3.

\begin{tabular}{|c|c|c|c|c|}
\hline & \multicolumn{2}{|c|}{ Украинские заговоры } & \multicolumn{2}{|c|}{ Плач Ярославны } \\
\hline Инвокационная & $\frac{\text { Юрию }}{\text { святий! }}$ & $\begin{array}{l}\text { Ніч темна, } \\
\text { ніч тишна, }\end{array}$ & $\begin{array}{l}\text { о Днепре } \\
\text { словутицю! }\end{array}$ & $\begin{array}{l}\text { о вђтрђ! } \\
\text { вьтрило! }\end{array}$ \\
\hline Эпическая & $\begin{array}{l}\text { пускаєш нори } \\
\text { принори, } \\
\text { луги, береги, } \\
\text { керниці- } \\
\text { теплиці, - }\end{array}$ & $\begin{array}{l}\text { сидиш ти } \\
\text { на коні була- } \\
\text { ному, в сідлі } \\
\text { соколиному, } \\
\text { замикаєш } \\
\text { ти комори, } \\
\text { дворці і хлів- } \\
\text { ці, церкви й } \\
\text { монастирі і } \\
\text { Київські } \\
\text { престоли. }\end{array}$ & $\begin{array}{l}\text { ты пробиль } \\
\text { еси каменныя } \\
\text { горы сквозь } \\
\text { землю По- } \\
\text { ловецкую. } \\
\text { Ты лельяль } \\
\text { еси на себъ } \\
\text { Святославли } \\
\text { носады } \\
\text { до пльку } \\
\text { Кобякова: }\end{array}$ & 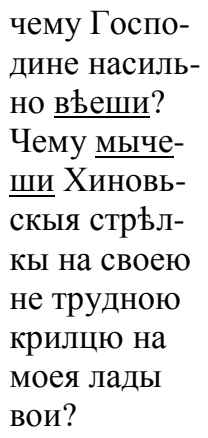 \\
\hline Лирическая & $\begin{array}{l}\text { тепер пусти } \\
\text { нам так ман- } \\
\text { ну-сметану, } \\
\text { ладне молоко, } \\
\text { густи сир, } \\
\text { жьовте масло! } \\
\text { (Гординський } \\
\text { 1963: 27) }\end{array}$ & $\begin{array}{l}\text { Замкни моїм } \\
\text { ворогам губи і } \\
\text { губища, щоки } \\
\text { i пращоки, очі } \\
\text { і праочі, щоб } \\
\text { вони на мене } \\
\text { нарожденну, } \\
\text { хрещену і } \\
\text { молитвовану } \\
\text { рабу Божу } \\
\text { зубів і очей } \\
\text { не витріщали, }\end{array}$ & $\begin{array}{l}\frac{\text { възлельй }}{\text { господине }} \\
\text { мою ладу къ } \\
\text { мнъ, а быхъ } \\
\text { неслала къ } \\
\text { нему слезъ } \\
\text { на море рано. }\end{array}$ & \\
\hline
\end{tabular}




\begin{tabular}{|l|l|l|l|}
\hline & гніва в серці \\
не мали, щоб & & \\
усе поважали & & \\
і в добрих & & \\
мислях мали & & & \\
& (Гординський & & \\
& $1963: 25)$. & & \\
\hline
\end{tabular}

И в плане содержания, и в плане языкового выражения параллели со «Словом» настолько разительны, что будет излишне их разъяснять. Остается только удивиться стойкости грамматических последовательностей в фольклорных текстах, ведь оба приведенных в таблице примера являются точным морфологическим соответствием обращений Ярославны к разным стихиям, но при этом между возможным фольклорным прототипом, который был стилизован автором «Слова», и записью украинских заклинаний прошло около восьми столетий.

\section{Параллели к индоевропейским компонентам «Плача Ярославны» и «Золотого слова Святослава» в языке украинских баллад}

Некоторые славянские баллады на мотивном и языковом уровнях происходят от общих текстовых прототипов, которые должны были существовать до распада праславянской языковой общности. Об этом говорят разительные текстовые схождения (во многих случаях дословные) между балладами восточных и западных славян (Линтур 1968: 72-73). Кроме того, вообще баллады имеют древнюю синкретическую связь с обрядовым фольклором (ГАнич 2007, Линтур 1965), а новогреческие баллады сохраняют ритуальные структуры, сходные со структурами древнегреческой трагедии (Коцовог 1991).

Некоторые украинские баллады сохранили трехчленную композицию индоевропейского гимна, отображенную и в проанализированных фрагментах «Слова». Некоторые баллады сохранили все три части, но большинство только эпическую и лирическую.

В балладе «Зайди, зайди, місяченьку, зайди за комору» (КРижАнгвсьКий 1981: 38) первая строчка - это заклинание, где сохранились обе граммемы, которые мы встретили в «Слове»- инвокационный вокатив місяченьку и произошедший от оптатива императив на $-u$. Эпической части соответствует диалог девушки с парнем, а лирической - заключительные строчки с проклятьем, которое герой адресует героине.

Особенно же хорошо сохранились морфологические последовательности, аналогичные микрогимнам «Слова», в балладе «Ой зима ж, зима лютая» (КрижАнІвський 1981: 141-142). После первых двух строчек, которые сконденсировано представляют морфемы инвокации и отчасти лирической части (Ой зима ж, зима лютая, / ой просю ж тебе, не зморозь мене, ср. о вътрб. вътрило), следует эпическая часть, грамматическим каркасом которой вы- 
ступают глагольные формы прошедшего времени, происходящие от причастия: полюбила, приголубила, взяла, зарізала, понесла и под. (ср. ты пробиль еси каменныя горы сквозъ землю Половеикую. Ты лельяль еси на себъ Святославли носады до плъку Кобякова). Наконец, заключительная строчка -

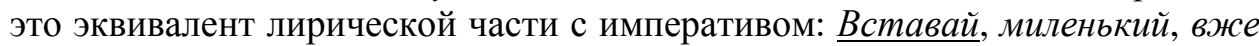
день біленький.

Однако большинство баллад сохраняет только эпическую и заключительную лирическую части. Обычно последняя принимает форму проклятия, которое произносит брошенная девушка или отравленный «чарами» парень. К этому типу относится множество текстов, но будет достаточно перечислить только некоторые: «Ой пійду я, пійду берегом-лугом» (КРИжАнІвСький 1981: 40-41); «Сеї ночі опівночі місячок мінився» (КРИЖАнІвський 1981: 56); «Ой у полі жито копитами збито» (КРИЖАнІвсьКий 1981: 49); «Ой на горі, горі» (КРИжАнІвський 1981: 81); «Їхав козак, їхав лугами-берегами» (КРижАНІВСьКИЙ 1981: 90-89).

Особенно примечательно, что заключительная часть баллады обычно вводится восклицаниями бодай, нехай, которые происходят от свободных словосочетаний Бог дай 'Бог даст', не хай 'не трогай' (Мвльничук 1: 221, МЕльничук 4: 81). В обоих прототипах глагол стоит именно в происходящей от индоевропейского оптатива форме на $-\breve{u}$, сохраняя в окаменевшем виде грамматическую форму глагола.

Украинские параллели говорят, что грамматические схемы, которыми пользовался автор «Слова», имеют прямые фольклорные истоки. Более детально об истоках грамматических последовательностей украинских баллад см. НАЗАРОВ 2014.

\section{Индоевропейские соответствия грамматическим последовательностям «Слова»}

Конечно, отдельные грамматические формы и морфемы употребляются в неисчислимом ряде контекстов. Однако их появление в таком четко регламентированном жанре, как гимны, молитвы и другие виды обращения к богам, не могло быть (и не было, как будет показано дальше) произвольным. Напротив, из ряда нескольких довольно близких по значению грамматических форм (и соответствующих им морфем) избиралась та, употребление коей было освящено многовековой традицией. Об этом говорят греческие (с формальным соответствием) и латинские (с функциональным) параллели к выявленным нами в «Слове» грамматическим последовательностям.

Все грамматические формы, наиболее присущие отдельным частям микрогимнов плача Ярославны и отдельным обращениям к князьям «Золотого слова» Святослава, имеют непосредственные параллели в греческих текстах. Индоевропейский суффикс вокатива *-e результировал не только в славянском -e, но и в греческом - $\varepsilon$ (BEEKES 1995: 186). Индоевропейский оптативный суффикс *-ieh $h_{1} / *-i h_{1}$ - отображен и в праславянских суффиксах -oi/-i/-е̌ (пере- 
осмысленных как окончание императива), и в формах древнегреческого оптатива - $\varepsilon l$ - в атематическом и -ol- (от $* o-i h_{1}$ ) в тематическом склонении, и в латинском оптативе глагола быть (sies 'чтобы ты был') (BEEKES 1995: 275, Мельничук 1966: 322).

Обратимся к самым архаичным древнегреческим источникам, к молитвам и микрогимнам, сохранившимся в составе «Илиады». Они известны как Homeric prayer (STRITTMATTER 1925) и в стилистическом оформлении существенно отличаются от более поздних древнегреческих образцов этого жанра (LATEINER 1997).

I. $\kappa \lambda \tilde{v} \theta \dot{1} \mu \varepsilon v \dot{\alpha} \rho \gamma v \rho o ́ \tau o \xi$

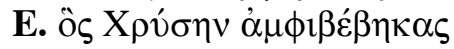

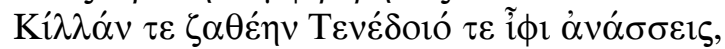

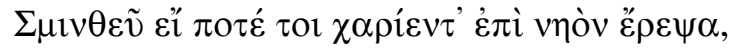

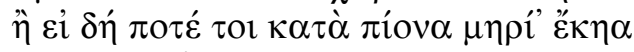

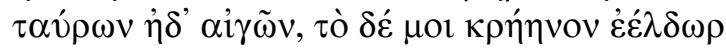

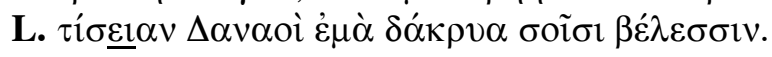

(Homer: Iliad. I, 37-42) ${ }^{2}$

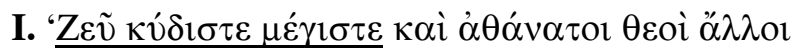

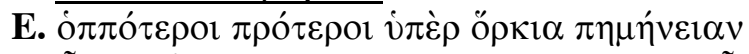

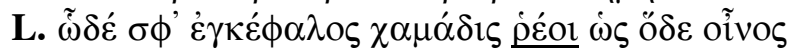

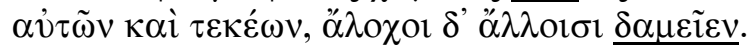

(Homer: Iliad. III, 298-301)

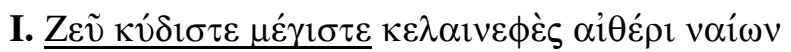

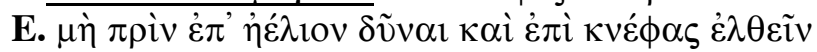

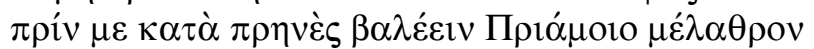

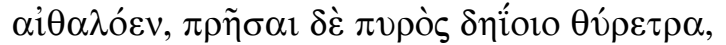

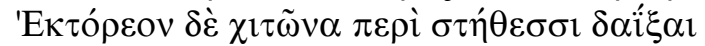

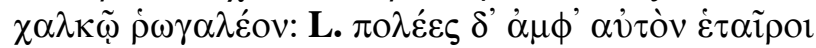

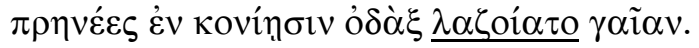

(Homer: Iliad. II, 413-418)

Эту же трехчленную схему особенно последовательно сохраняют орфические гимны. В заключительной («лирической») части орфических гимнов чаще используется императив, однако оптатив сохраняется в ряде примеров, в том числе в выражении, которое формульно повторяется в заключительных строчках нескольких гимнов:

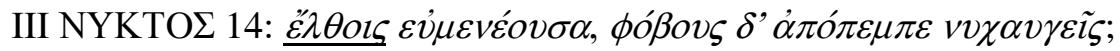

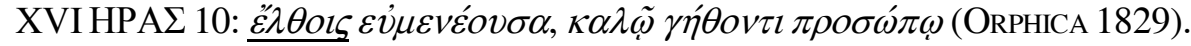

\footnotetext{
${ }^{2}$ Греческие тексты, если источник не оговорен отдельно, подаются по ресурсам сайта http://www.perseus.tufts.edu/hopper/collections.
} 
В гимне D1 Сапфо, обращенном к Афродите, в лирической части исполь-

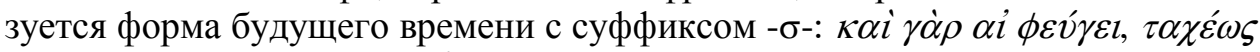

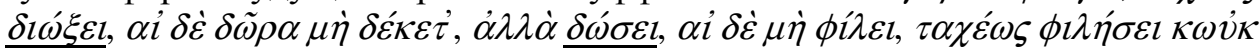
$\dot{\varepsilon} \theta \dot{\varepsilon} \lambda o l \sigma \alpha$. Эта форма, хотя и не имеет явного оттенка оптативности, восходит к индоевропейской модальной, желательной форме глагола (BEEKES 1995: 257). То есть первично в греческой традиции лирическую часть обязательно сопровождала желательная модальность глагола, впоследствии вытесненная императивом, как в заключительных строчках некоторых гомеровских и многих орфических гимнов.

Кроме греческого и славянского отображения оптатива, существует еще латинский рефлекс, который остался только в составе старого оптатива глагола быть (BEEKES 1995: 275). Именно эта форма отображена в одном из древнейших молитвенных текстов, обращенных к Марсу: I. Mars pater E. te precor quaesoque L. uti sies volens propitius mihi domo familiaeque nostrae (WATKINS 1995: 199).

Особенно важно использование вокатива в инвокационной части $(Z \varepsilon \dot{v}$

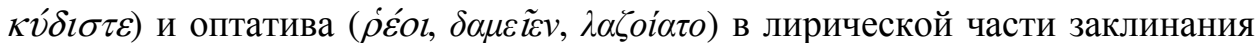
в гомеровском отображении индоевропейского гимна. Эта форма выглядит на фоне позднейших текстов греческих гимнов как архаизм, ее постепенно вытеснил императив (с суффиксом - $\varepsilon$ или голой основой). Ей же соответствует латинская форма sies в молитве к Марсу. Но ведь форма греческого оптатива, который присущ лирической части гомеровской молитвы, генетически родственна славянскому императиву, который мы увидели в «Слове о полку Игореве», украинских заговорах и (в том числе в окаменелой форме) в заключении украинских баллад! То есть, греческий материал подтверждает высказанную выше гипотезу об индоевропейском происхождении грамматических последовательностей в микрогимнах «Слова о полку Игореве».

\section{Реконструкция исходной схемы индоевропейского источника «Плача Ярославны» и «Золотого слова Святослава»}

Мы осознаем, что индоевропейский гимн мог иметь разнообразное грамматическое оформление, однако перед нами и не стоит задача реконструировать все возможные его варианты. Напротив, нас интересует индоевропейский прототип микрогимнов «Слова о полку Игореве». Исходя из проанализированных текстов других индоевропейских традиций, можно предложить два варианта такой реконструкции: один более общий, другой более конкретный, с предположительными грамматическими формантами.

Пусть $\mathrm{N}$ = имя существительное (или же, в конкретизированной схеме, именная основа), $\mathrm{V}=$ глагол (глагольная основа), vос = звательный падеж, opt $=$ оптатив, indir = любая форма имени, кроме звательного и именительного падежа, ind = любая форма глагола в изъявительном наклонении, fin личные окончания глагола, «+» = знак соединения, «/» = знак «и/или». 
В таком случае общая схема реконструируемой праформы гимна будет иметь следующий вид:
I. $\mathrm{N}_{\text {voc }}$
E. $\mathrm{V}_{\text {ind }}+\mathrm{N}_{\text {indir }}$
L. $\mathrm{V}_{\text {opt }}+\mathrm{N}_{\text {indir }}$

А более конкретная схема грамматических последовательностей может выглядеть как представление наиболее характерных для каждой части грамматических форм:

$$
\begin{aligned}
& \text { I. } \mathrm{N}+*_{e} \\
& \text { E. }(\mathrm{V}+\text { ind })+(\mathrm{N}+\text { indir }) \\
& \text { L. }\left(\mathrm{V}+*_{-} i h_{1}-/ *_{-} i e h_{1}+\text { fin }\right)+(\mathrm{N}+\text { indir })
\end{aligned}
$$

\section{Все дороги ведут в Рим, а рефлексы - к прототипу}

В этом исследовании мы попытались объединить «синхронный» подход к формуле, используемый в фольклористике, с диахронным, который применяется в сравнительно-исторической поэтике. И в каждом отдельном случае (микрогимны «Слова о полку Игореве», украинские фольклорные тексты) синхрония фольклора оказывалась углубленной на много тысячелетий в общее индоевропейское прошлое.

Морфологические последовательности индоевропейского гимна оказались настолько стабильны, что прийти к ним можно было, начиная путь от любого из его отображений. Начав движение то ли от молитв гомеровских героев, то ли от заклинания римского пахаря, то ли от сетований Ярославны, или от украинских заклинаний и баллад, - все равно придешь к индоевропейскому прототипу.

Резюмируя проведенный анализ, можно сказать, что «Плач Ярославны» и «Золотое слово Святослава» сохранили общеиндоевропейскую композиционную и морфологическую канву. О том, что она не была результатом имитации, свидетельствуют параллели между гимнами «Слова» и древнейшими славянскими письменными текстами, украинским фольклором, с одной стороны, и древнегреческой гимнографией и латинскими заклинаниями, с другой. Наиболее существенно, что эти параллели прослеживаются не только на уровне отдельных генетически родственных морфем, но также и на уровне цельх цепочек этимологически родственных грамматических формантов. Это может служить еще одним веским аргументом в пользу аутентичности «Слова», так как этимологические соответствия грамматических формантов индоевропейских языков в конце XVIII века еще не были известны настолько отчетливо. Кроме того, фальсификатору понадобилось бы в таком случае подделывать не само «Слово», а гомеровские тексты, так как именно язык последних позволял выразить то же модальное грамматическое значение, но другими формами, генетически не родственными славянскому императиву 
(например, древним индоевропейским императивом, не сохранившимся в славянских языках). Таким образом, последовательности морфем принадлежат к тем особенностям языка «Слова», которые вряд ли удалось бы сымитировать в XVIII в., так же как показанную А. А. Зализняком дистрибуцию частиц (ЗАлизняк 2008: 418-419).

Какое же отношение к ритуальным действиям имеют последовательности морфем, обнаруженные нами в «Слове» и других реликтах индоевропейского гимна? Лексика отображает мир и его структуру. А морфемы вообще, тем более в ритуализированной речи, функционируют как носители отношения к миру, воплощают вектор возможного действия. Иными словами, морфемы гимна в наиболее лапидарной форме выражают то же, что на иных уровнях ритуала выражено действиями и нарративами.

Особенно ярко это можно видеть, сравнив последовательности морфем с последовательностью композиционных частей в сибирском шаманском обряде. Последовательность и нарративное содержание частей шаманского ритуала взяты нами из самих текстов камланий (Анохин 1924) и из их этнографического и семиотического анализа (АлЕксеЕв 1984, Новик 2004). Так, инвокационная часть гимна (с характерной морфемой вокатива) есть не что иное, как «собирание силы» в шаманском обряде: шаман обращается к духампокровителям. Следующая за ней эпическая часть гимна (которой присущ только индикатив и где отсутствует измененная модальность) соотносима с нарративной по сути частью камлания: шаман рассказывает о своем пути в потусторонний мир, встречает препятствия и противников. Обе эти части и в гимнах «Слова», и в камлании характеризуются констатацией, описательным отношением к действительности. И только заключительная часть гимна, лирическая, направлена на изменение действительности (только ей в гимне присуще употребление желательной и императивной модальности; изъявительное наклонение вообще для нее не характерно). Так же и вторая половина камлания - это изменяющее реальность ядро ритуала: шаман после пути вступает в противоборство с владыкой потустороннего мира, излечивает больного, возвращая ему душу, иногда дает прогноз (то есть императивно программирует поведение социума).

Иными словами, обнаруженные последовательности морфем мотивированы основами ритуального и мифологического мировосприятия и кодируют на микроуровне то же, что закодировано на макроуровне в нарративах и действиях. Поэтому данному исследованию можно было бы возразить, как и всем исследованиям общеиндоевропейского поэтического языка, что оно реконструирует общие места всех фольклорных традиций: структура ритуала имеет много общего на всех континентах и это не могло отобразиться в структуре языкового сопровождения.

Однако с развитием исследований отдаленного родства языков ширится круг фольклорных традиций, которые могут иметь генетически общие элементы, и не исключено, что таковые есть между тюркскими (или шире - алтайскими) и индоевропейскими языками (данный вопрос был нами затронут 
в другой работе, ср. НАзАРОВ 2013). А с другой стороны, реконструируемые нами морфологические последовательности показывают своеобразие именно индоевропейского языкового воплощения ритуальных структур, независимо от происхождения последних.

\section{Литература}

АЛЕКСЕЕВ 1984 = АЛЕКСЕеВ Н. А. Шаманизм тюркоязычных народов Сибири. Опыт ареального сравнительного исследования. Новосибирск, 1984.

Анохин 1924 = Анохин А. В. Материаль по шаманству у алтайцев. Ленинград, 1924.

ГАнич $2007=$ ГАнІч О. М. Проблема походження украӥнської народної балади. АКД. Львів, 2007.

Гординський 1963 = Гординський С. Я. «Слово о полку Ігоревім» і украйнська народна поезія. Вибрані проблеми. Вінніпег, 1963.

ЗАлизняк 2008 = ЗАлизняк А. А. «Слово о полку Игореве»: взгляд лингвиста. Москва, 2008.

ИвАНОВ $1979=$ ИвАНОВ Вяч. Вс. К проблеме следов древнейшего литературного языка у славян. В кн.: ДЕминА Е. И. (ред.) История литературныхх языков и письменность. (Славянское и балканское языкознание 5.) Москва, 1979. 5-25.

ИвАнОВ-ТоПОРОВ 1963 = ИвАнОВ Вяч. Вс., ТоПоРОВ В. Н. К реконструКции праславянского текста. В кн.: Славянское языкознание. Доклады советской делегаиии. V Международный съезд славистов. Москва, 1963. 88-158.

ИвАНОВ-ТОПОРОВ 1965 = ИвАНОВ Вяч. Вс., ТоПОРОВ В. Н. Славянские языковые моделируюшие системы. Древний период. Москва, 1965.

КАГАРОВ 1981 = КАГАРОВ Е. Г. Словесные элементы обряда. В кн.: ГОРЕЛОВ А. А. (ред.) Из истории русской советской фольклористики. Москва, 1981. 66-76.

КРИЖАНІВСьКИй 1981 = КРИЖАНІВСьКИй С. А. (ред.) Балади. Київ, 1981.

Куев 1974 = Куев К. М. Азбучната молитва в славянските литератури. София, 1974.

Линтур 1965 = Линтур П. Балладная песня и обрядовая поэзия. Русский фольклор 10 (1965): 228-236.

Линтур 1968 = Линтур П. Новые записи балладной песни «О сестре-отравительнице». Проблема происхождения балладной песни. Slavia 38 (1968): 59-82.

Мельничук = Мельничук О. С. (гол. ред.) Етимологічний словник украӥнської мови. Т. 1-7. Київ, 1983-2012.

МЕльничук 1966 = Мельничук О. С. (ред.) Вступ до порівняльно-історичного вивчення слов'янських мов. Київ, 1966.

МосенкИС 2006 = МосенкИС Ю. Л. Поэтическая реконструкция «Слова о полку Игореве» и летописная поэзия. Киев, 2006.

НАДь 2002 = НАДь Г. Греческая мифология и поэтика. Москва, 2002.

НАЗАРОВ 2013 = НАзАРОВ Н. А. Морфологічні паралелі між заклинаннями «Калевали» та алтайськими шаманськими камланнями у зв'язку з індоєвропейською гімнографічною традицією (до поетики ностратичного фольклору). Мова та історія 250 (2013): 34-53.

НАЗАРОВ 2014 = НАЗАРОВ Н. А. Індоєвропейське та ностратичне походження граматичних послідовностей мови українських народних балад. Мова та історія 305 (2014): 4-12. 
Новик 2004 = Новик Е. С. Обряд и фольклор в сибирском шаманизме. Oпьт сопоставления структур. Москва, 2004.

ТопОРОВ 1969 = ТопОРОВ В. Н. К реконструкции индоевропейского ритуала и ритуально-поэтических формул (на материале заговоров). Труды по знаковым системам IV. Tartu, 1969. 9-43.

ТопоРов 1979 = ТопоРов В. Н. «Проглас» Константина Философа как образец старославянской поэзии. В кн.: ДЕмИНА Е. И. (ред.) История литературных языков и письменность. (Славянское и балканское языкознание 5.) Москва, 1979. 26-46.

Топоров 2012 = Топоров В. Н. Пиндар и Ригведа. Москва, 2012.

BEEKES 1995 = BEEKES R. S. P. Comparative Indo-European Linguistics. An Introduction. Amsterdam-Philadelphia, 1995.

LATEINER 1997 = LATEINER D. Homeric prayer. Arethusa 30 (1997): 241-272.

LEONI 1968 = LEONI F. A. Quelques observations sur la indogermanische Dichtersprache. Studia Linguistica 22 (1968): 124-128.

LORD 1971 = LORD B. A. The Singer of Tales. New York, 1971.

ORPHICA 1829 = Orphica. Procli Hymni. Musaei Carmen de Hero et Leandro. Callimachi hymni et epigrammata. Lipsiae, 1829.

RISCH 1969 = RISCH E. Dichtung und Dichtersprache in indogermanischer Zeit. Indogermanische Dichtersprache von Rüdiger Schmitt. Gnomon 41 (1969): 321-327.

SCHMITT 1967 = SCHMITT R. Dichtung und Dichtersprache in indogermanischer Zeit. Wiesbaden, 1967.

StritTMATter $1925=$ StritTMatTer E. J. Prayer in the Iliad and the Odyssey. The Classical Weekly 1925/11: 83-87, 1925/12: 90-92.

WatKIns $1995=$ W AtKIns C. How to Kill a Dragon. New York-Oxford, 1995.

West 2007 = West M. L. Indo-European Poetry and Myth. Oxford, 2007.

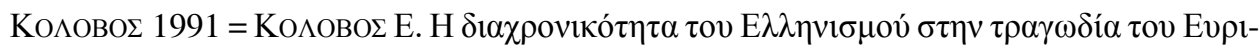
$\pi i \delta \eta \eta$ « 90-91 (1991): 153-160. 